\title{
SISTEM PENGENDALIAN INTERNAL ATAS PENJUALAN BARANG DAGANGAN (Studi Kasus di Toko Sumber Rejo Semarang)
}

\author{
Novita Anjarsari ${ }^{1}$ \\ Saifudin ${ }^{2}$ \\ viansa_rolnqyu@yahoo.com ${ }^{1}$ \\ saifudin@usm.ac.id ${ }^{2}$
}

Fakultas Ekonomi Universitas Semarang

\section{Diterima: Mei 2020, Disetujui: Juni 2020, Dipublikasikan: Juli 2020}

\begin{abstract}
This study aims to analyze internal control system for selling merchandise in a Toko Sumber Rejo Semarang. Trade Methods used in this study is the method descriptive qualitative data analysis using triangulation. Data collection method is by observation, on the interviews and documentation.

According to the analysis that has been done in a Toko Sumber Rejo we can conclude that the internal control system is still cannot trade an selling merchandise is said both because there is no adequate the organizational structure and there is a double function in the implementation of the tasks and responsibilities and any negligence in recording supplies store employee that cause the mismatch between the number of physical amount of merchandise and the supply system.

Keywords: Toko Sumber Rejo, internal control, sales of merchandise
\end{abstract}

\begin{abstract}
ABSTRAK
Penelitian ini bertujuan untuk menganalisis sistem pengendalian internal atas penjualan barang dagangan pada Toko Sumber Rejo Semarang. Metode yang digunakan dalam penelitian ini adalah metode deskriptif kualitatif dengan Teknik analisis data menggunakan triangulasi. Metode pengumpulan data yang dilakukan adalah dengan metode observasi, wawancara, dan dokumentasi.

Berdasarkan analisis yang telah dilakukan pada Toko Sumber Rejo Semarang dapat disimpulkan bahwa sistem pengendalian internal atas penjualan barang dagangan masih belum bisa dikatakan baik karena tidak adanya struktur organisasi yang memadai serta masih adanya fungsi ganda dalam pelaksanaan tugas dan tanggung jawab dan adanya kelalaian karyawan toko dalam pencatatan persediaan sehingga menyebabkan terjadinya ketidaksesuaian antara jumlah fisik persediaan barang dagang dengan sistem stok persediaan barang.

Kata Kunci: Toko Sumber Rejo, Pengendalian Internal, Penjualan Barang Dagang.
\end{abstract}

\section{PENDAHULUAN}

\section{Latar Belakang}

Dengan semakin berkembangnya era globalisasi saat ini menjadikan banyak perusahaan-perusahaan besar maupun usaha kecil menengah (UKM) mengalami persaingan yang sangat ketat, baik dalam bidang teknologi informasi dan ilmu pengetahuan mengalami peningkatan dan kemudahan salah satunya dalam pencatatan dan pengelolaan persediaan barang dalam suatu perusahaan. Dimana dalam perusahaan dagang persediaan memiliki peran yang sangat penting karena merupakan factor yang mempengaruhi kelancaran jual beli dalam kegiatan usaha. Oleh karena itu persediaan 
sangat perlu dijaga, salah satu dengan pengendalian internal supaya dapat mengurangi terjadinya resiko terjadi selisih, kehilangan barang, dan kemungkinan terjadinya kecurangan.

Toko Sumber Rejo merupakan usaha atau bisnis keluarga yang bergerak di bidang perdagangan peralatan besi, lampu, dan kompor. Dimana dalam usaha Toko Sumber Rejo juga dilaksanakan pengendalian internal untuk menjaga persediaan barang dengan melakukan pembentukan struktur organisasi, pelaksanaan sistem wewenang dan prosedur pencatatan menggunakan sistem perpetual dan stok opname. Namun dalam pelaksanaannya persediaan barang pada Toko Sumber Rejo masih mengalami selisih atau ketidaksesuaian antara stok persediaan barang dagang fisik dengan stok pada sistem persediaan barang. Berdasarkan uraian masalah diatas dan fenomena tersebut maka penulis mengambil judul: " Analisis Sistem Pengendalian Internal Atas Penjualan Barang Dagangan Di Toko Sumber Rejo".

\section{Rumusan Masalah}

Rumusan masalah dalam hal ini dapat dijabarkan kedalam pertanyaan masalah yaitu:

1. Bagaimana penerapan sistem pengendalian internal atas penjualan barang dagangan di Toko Sumber Rejo Semarang?

2. Apakah sistem pengendalian internal atas penjualan barang dagangan di Toko Sumber Rejo Semarang sudah berjalan dengan efektif?

3. Apakah penyebab dari kesalahan dalam melakukan pengendalian internal atas penjualan barang dagangan di Toko Sumber Rejo Semarang?

\section{Tujuan Penelitian}

Tujuan penelitian ini untuk mengetahui sistem pengendalian internal atas persediaan penjualan barang dagangan di Toko Sumber Rejo Semarang dan juga penyebab kesalahan dalam melakukan pengendalian internal. 


\section{TINJAUAN PUSTAKA}

\section{Sistem}

Menurut (Mulyadi, 2017) sistem pada dasarnya adalah sekelompok unsur yang erat berhubungan satu dengan yang lainnya, yang berfungsi bersama-sama untuk mencapai tujuan tertentu. Sistem Informasi Akuntansi adalah metode dan prosedur untuk mengumpulkan, mengelompokkan, merangkum serta melaporkan informasi keuangan dan operasi perusahaan yang dibutuhkan oleh manajemen guna memudahkan pengelolaan perusahaan. Sistem Informasi Akuntansi memiliki beberapa unsur yang berupa:

1. Formulir

2. Jurnal

3. Buku Besar

4. Buku Pembantu

5. Laporan

\section{Pengendalian Internal}

Pengendalian internal menurut ( C.S. Warren, 2017) adalah kebijakan dan prosedur yang melindungi aset dari penyalahgunaan, memastikan keakuratan informasi bisnis, serta memastikan hokum dan peraturan yang berlaku telah diikuti. Tujuan pengendalian internal adalah memberikan keyakinan yang wajar bahwa operasi dikelola untuk mencapai suatu tujuan tertentu, laporan keuangan yang akurat, serta hokum dan peraturan dipenuhi.

Unsur-unsur sistem pengendalian internal yaitu:

1. Struktur organisasi yang memisahkan tanggung jawab fungsional secara tegas.

2. Sistem wewenang dan prosedur pencatatan yang memberikan perlindungan yang cukup terhadap Aset, Utang, Pendapatan, dan Beban.

3. Praktik yang sehat dalam melaksanakan tugas dan fungsi setiap unit organisasi.

4. Karyawan yang mutunya sesuai dengan tanggung jawabnya.

\section{Persediaan}

Persediaan dalam perusahaan dagang hanya terdiri dari satu jenis, yaitu persediaan barang dagang, yang merupakan barang yang dibeli untuk dijual kembali. Menurut Earl K. Stice dan K. Fred Skousen (2004) persediaan merupakan barangbarang yang tersedia untuk dijual dalam kegiatan bisnis normal dan dalam kasus 
perusahaan manufaktur, maka kata ini ditujukan untuk barang dalam proses produksi atau yang ditempatkan dalam kegiatan produksi.

Metode Pencatatan Persediaan ada dua yaitu:

1. Metode Perpetual

Pencatatan yang selalu dimutakhirkan setiap kali terjadi transaksi yang melibatkan persediaan, sehingga perusahaan selalu mengetahui kuantitas dan nilai persediaannya setiap saat.

2. Metode Persediaan Fisik

Hanya tambahan persediaan dari pembelian saja yang dicatat, sedangkan mutase berkurangnya persediaan tidak dicatat dalam kartu persediaan sehingga untuk mengetahui berapa sisa persediaan yang ada harus dilakukan perhitungan fisik.

Metode Penilaian Persediaan yaitu:

1. Metode FIFO

Penjualan barang ini berdasarkan urutan yang sama dengan saat barang dibeli dan biaya diasumsikan dalam harga pokok penjualan dengan urutan yang sama saat biaya tersebut terjadi.

2. Metode LIFO

Barang yang dibeli terakhir harus dijual atau dikeluarkan terlebih dahulu. Bila penjualan barang yang terakhir melebihi jumlah pembelian barang dagang yang terakhir maka diambilkan pada pembeliaan sebelumnya.

\section{Metode Average}

Biaya persediaan per unit merupakan rata-rata biaya pembelian. Karena harga pokok rata-rata baru dihitung pada akhir periode.

\section{Hasil Penelitian Sebelumnya}

Dari Penelitian sebelumnya yang juga mengambil studi kasus analisis pengendalian internal terdapat beberapa contoh yang dapat digunakan sebagai pendukung dari penelitian ini yaitu:

1. Fernando (2016) yang melakukan penelitian pada PT. Meskom Argo Sarimas menyimpulkan bahwa hasil prosedur sistem informasi akuntansi 
persediaan dan kebijakan diterapkannya unsur-unsur pengendalian internal persediaan sudah terlaksana dengan cukup efektif.

2. Irna et.al (2016) menganalisis sistem pengendalian intern persediaan obat di rumah sakit anak Astrini Wonogiri menunjukkan hasil bahwa penerapan sistem pengendalian sudah berjalan dengan efektif, namun masih terdapat kekurangan yaitu belum adanya pemisahan tugas.

3. Fitri dan Erni (2017) penelitian ini dilakukan di CV. Sumber Alam Sejahtera dengan hasil unsur-unsur dalam pengendalian intern pada CV. Sumber Alam Sejahtera belum berjalan dengan baik karena dalam fungsi penerimaan dan penyimpanan masih merangkap menjadi satu fungsi yang menyebabkan kurang ketelitian karyawan dalam pencatatan.

4. Suprajitno (2018) penelitian dilaksanakan pada PT. Surya Indah Kebumen dengan hasil diketahui bahwa pengendalian internal belum berjalan baik karena masih belum menggunakan formulir bernomor urut tercetak dan juga kurang efektifnya fungsi-fungsi yang terkait.

5. Rizki (2018) penelitian dilaksanakan pada CV. Celine Production dengan hasil sistem informasi akuntansi dalam fungsi dan dokumen serta sistem pengendalian internal tidak sesuai dengan teori yang ada.

\section{Alur Penelitian}

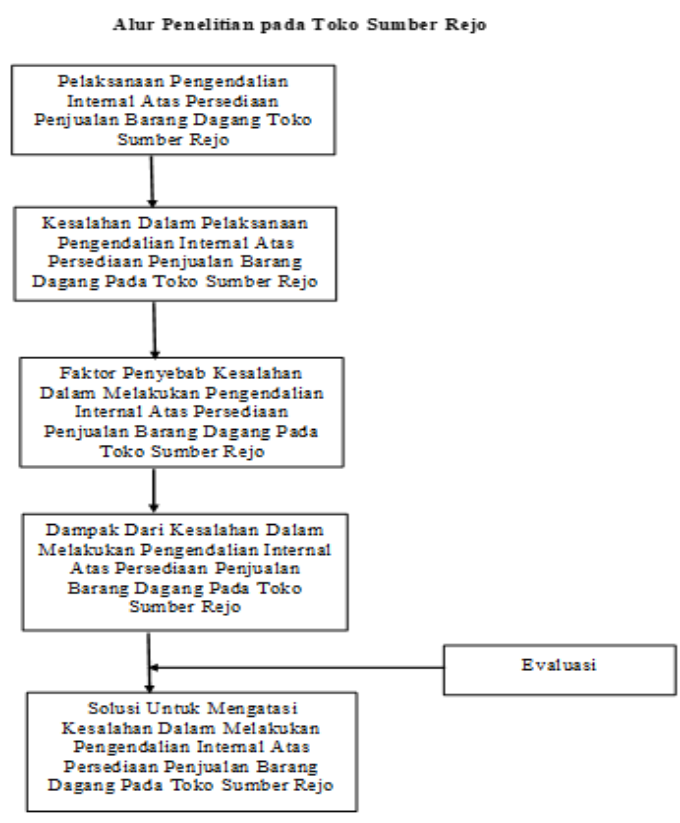




\section{METODE PENELITIAN}

\section{Jenis Penelitian}

Penelitian ini adalah penelitian jenis Case Study (Studi Kasus). Penelitian studi kasus menurut (Gunawan, 2015) adalah penelitian yang meneliti fenomena kontemporer secara utuh dan menyeruluh pada kondisi yang sebenarnya, dengan menggunakan berbagai sumber data. Dengan metode yang digunakan adalah deskriptif kualitatif, serta jenis data yang digunakan adalah Data Primer dan Data Sekunder.

\section{Metode Pengumpulan Data}

1. Metode Observasi

Merupakan suatu Teknik pengumpulan data yang dilakukan dengan cara mengadakan penelitian secara teliti, serta pencatatan secara sistematis (Arikunto, 2002).

2. Metode Wawancara

Menurut (Setyadin, 2005) wawancara adalah suatu percakapan yang diarahkan pada suatu masalah tertentu, ini merupakan proses tanya jawab lisan, dimana dua orang atau lebih berhadap-hadapan secara fisik.

3. Metode Dokumentasi

(Sugiyono, 2007) merupakan catatan peristiwa yang sudah berlalu yang berbentuk tulisan, gambar, atau karya monumental dari seseorang. Dokumentasi merupakan pelengkap dari penggunaan metode observasi dan wawancara.

\section{Teknik Analisis Data}

Teknik analisis data pada penelitian ini terdiri dari:

A. Uji Kredibilitas Data

1. Triangulasi Sumber adalah membandingkan (mengecek ulang) informasi yang diperoleh melalui sumber yang berbeda.

2. Triangulasi Metode adalah usaha mengecek keabsahan data atau mengecek keabsahan temuan penelitian.

B. Narasi Data 


\section{HASIL DAN PEMBAHASAN}

\section{Analisis Data}

Berdasarkan hasil wawancara pada Toko Sumber Rejo Semarang dapat disimpulkan bahwa pengendalian internal yang dilaksanakan pada toko mencakup struktur organisasi, pembagian tugas dan tanggung jawab, otorisasi pimpinan, keteraturan dalam pelaksanaan stok opname dan juga dalam bukti dokumen transaksinya sudah berjalan cukup baik, dinilai dari bentuk usaha yang termasuk kedalam UMKM atau usaha kecil menengah. Menurut hasil wawancara tertulis maupun langsung dari informan menilai baha struktural yang ada pada Toko Sumber Rejo dinilai cukup baik karena tidak memerlukan struktural yang sesuai dengan standar perusahaan besar. Hal ini menimbulkan tugas dan tanggung jawab yang diberikan tidak sesuai dengan bagian yang mereka kerjakan, contoh bagian gudang yang juga ikut melaksanakan fungsi toko. Untuk segi bukti transaksi sudah berjalan dengan baik semua transaksi sudah diotorisasi oleh pimpinan sehinggan semua barang yang masuk maupun keluar diketahui oleh pimpinan namun untuk nota transaksi yang digunakan pada Toko Sumber Rejo masih menggunakan catatan manual yang diurutkan sesuai penjualan hari itu. Untuk penjualan barang dagang Sumber Rejo menggunakan metode FIFO dimana barang yang dijual ke pelanggan diambilkan dari persediaan barang yang masuk pertama selain itu pencatatan yang dilaksanakan pada Toko Sumber Rejo adalah menggunakan metode perpetual yang dimana pencatatan yang selalu diperbarui setiap kali terjadi transaksi yang melibatkan persediaan.

\section{Pembahasan}

A. Sistem dan Prosedur Persediaan Penjualan Barang Dagang Pada Toko Sumber Rejo

Pada sistem dan prosedur persediaan penjualan barang dagangan dan pembelian barang dagangan pada Toko Sumber Rejo, semua transaksi terjadi melalui otorisasi pimpinan dimana pimpinan atau bagian penjualan akan melaksanakan tugas pertama yaitu sebagai penerima maupun pembeli barang untuk persediaan yang selanjutnya akan membuatkan bukti nota transaksi sebanak 3 lembar (asli, copy, dan surat jalan) yang akan diserahkan ke bagian toko 2 lembar (asli dan surat jalan) untuk pengambilan barang orderan, namun apabila barang tidak tersedia di toko maka akan diambilkan ke gudang dengan menyerahkan nota serta bukti pengambilan barang untuk catatan bagian 
gudang setelah itu barang akan diantarkan ke pelanggan dengan dibarengi nota penjualan dan juga surat jalan. Kemudian 1 nota copyan akan diserahkan ke bagian administarsi guna untuk menginput data penjualan pada sistem yang tersedia

\section{Flowchart Penjualan Tunai Barang Dagangan Pada Toko Sumber Rejo}

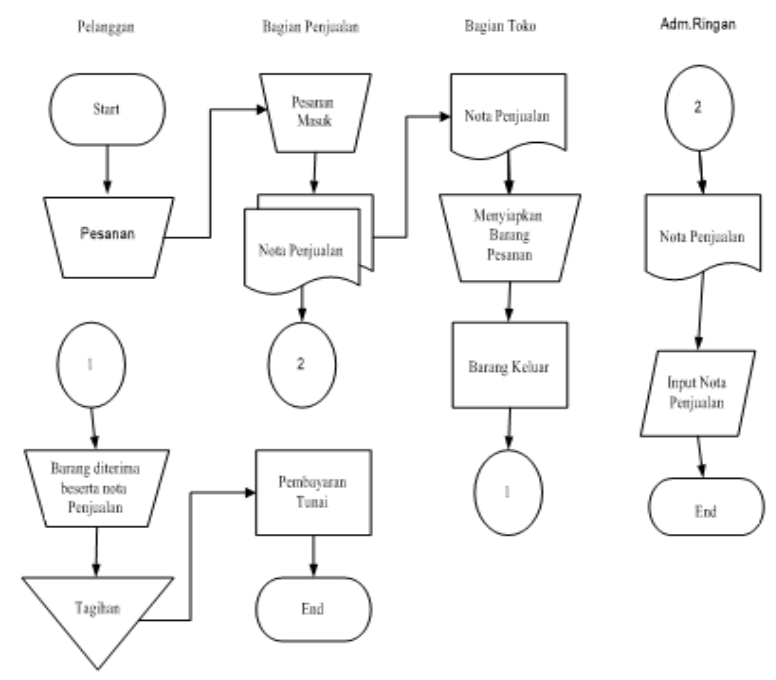

2. Flowchart Penjualan Kredit Barang Dagangan Pada Toko Sumber Rejo
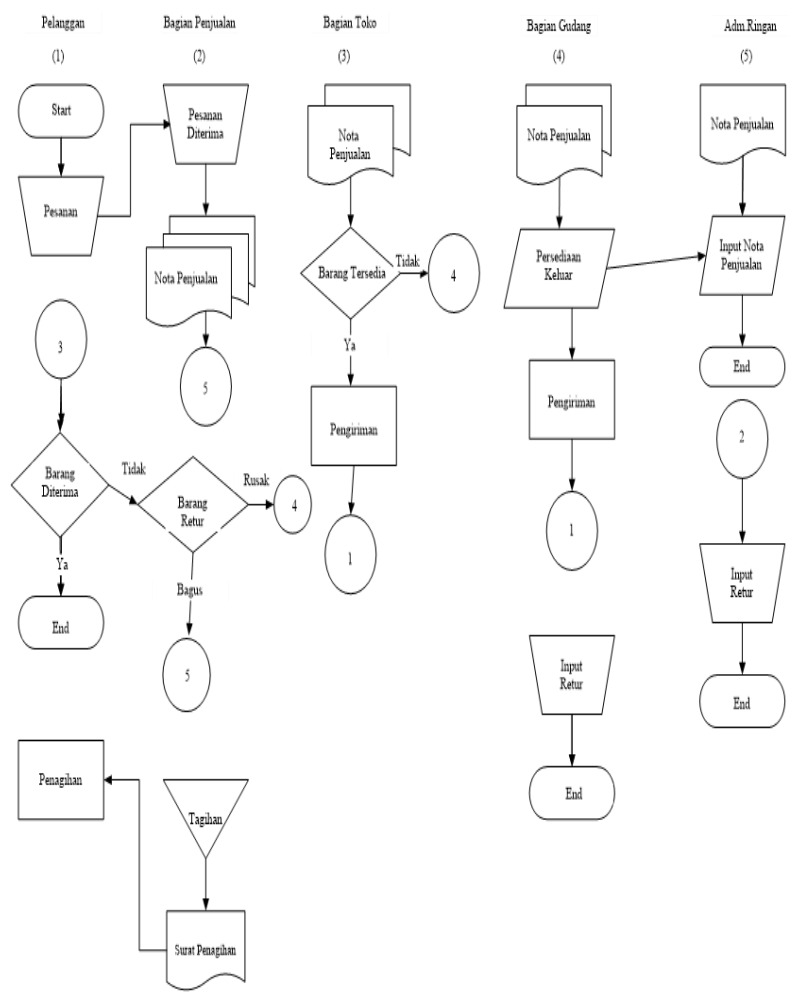
3. Flowchart Pembelian Barang Dagangan Toko Sumber Rejo

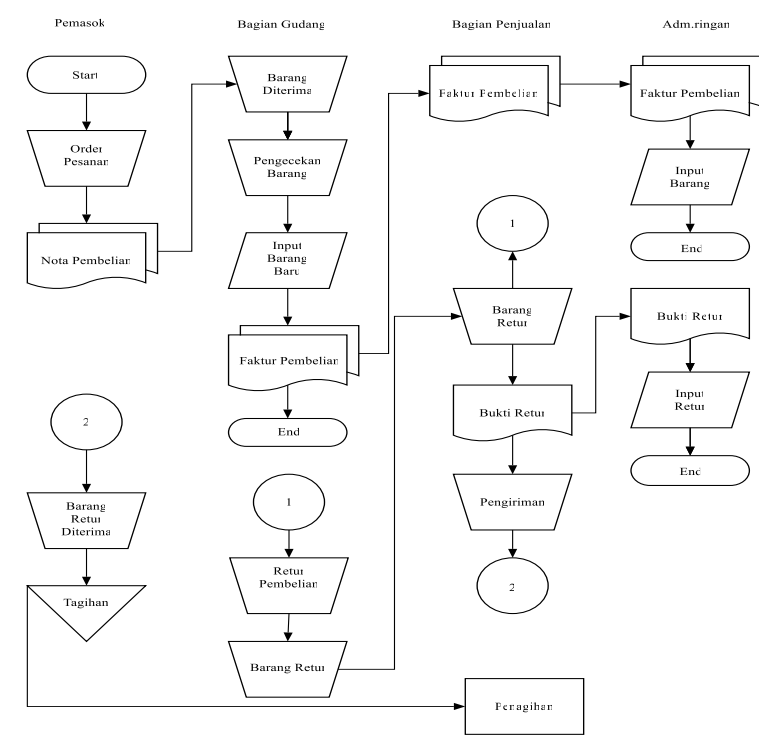

\section{Sistem Pencatatan Persediaan Pada Toko Sumber Rejo}

Pencatatan persediaan yang dilaksanakan pada Toko Sumber Rejo menggunakan sistem perpetual dimana pencatatan akan diperbaruhi setiap kali terjadinya transaksi pembelian, penjualan, dan retur atau yang berkaitan dengan persediaan barang dagangnya. Hal ini dilakukan untuk mengetahui ataupun menjamin keakuratan jumlah persediaan maka pada periode tertentu akan dilakukan perhitungan secara fisik pada stok persediaan yang ada pada Toko Sumber Rejo Semarang.

\section{Identifikasi Masalah Pengendalian Internal Atas Barang Dagang Pada Toko Sumber Rejo}

1. Ketelitian Karyawan saat menjalankan tugas dan tanggung jawabnya

Hal ini disebabkan oleh karena banyaknya jenis barang yang memiliki merek dan ukuran yang beraneka ragam. Selain itu karena nota penjualan masih menggunakan nota manual yang ditulis tangan, terkadang terjadi ketidakselarasan antara nama barang yang di catat di nota pembelian dengan nama barang yang ada pada komputer sehingga terjadi kekeliruan saat memotongkan stok barang. 
2. Pengendalian Internal Toko Sumber Rejo yang belum berjalan dengan baik dan tepat

Tidak adanya struktur yang tepat menjadikan tugas dan tanggung jawab setiap fungsi tidak dapat berjalan dengan baik. Hal ini terjadi dikarenakan tidak adanya pemisahan antara fungsi bagian dimana fungsi gudang bisa menjalankan fungsi pegawai toko. Oleh karena itu tugas dan tanggung jawab setiap bagian tidak dapat berjalan dengan efisien dan tepat.

3. Tidak adanya audit internal di dalam Toko Sumber Rejo

Dengan kata lain pimpinan bekerja secara individu dalam menjalankan penilaian serta tidak adanya bantuan yang diterima oleh pimpinan dalam hal pemberi masukan ataupun pemeriksaan guna untuk mendukung berjalannya manajemen perusahaan sebagai fungsi controlling yang menjamin perusahaan berjalan sesuai dengan perencanaan tujuan.

\section{Alternatif yang solusi untuk penyelesaian permasalahan Toko Sumber Rejo Semarang}

1. Karena masih adanya fungsi ganda pada pelaksanaan tugas dan tanggung jawab karyawan Toko Sumber Rejo, dimana hal ini menjadikan salah satu penyebab terjadinya selisih atau kekeliruan stok persediaan penjualan barang dagang maka seharusnya Toko Sumber Rejo mengadakan pemisahan tugas fungsi dimana antara fungsi pencatatan gudang dan fungsi toko harus melaksanakan tugas dan tanggung jawab yang terpisah walaupun Toko Sumber Rejo dalam kegiatan usaha termasuk di dalam kelas UMKM namun perlu juga memperhatikan fungsi setiap karyawannya. Serta perlu dilaksanakan pencocokan fisik aset dengan sistem secara periodik, walau pada dasarnya Toko Sumber Rejo setiap tahun sekali akan melaksanakan stok opname hal ini guna untuk menjaga dan mengecek ketelitian dan keandalan catatan akuntansinya.

2. Selain itu di Toko Sumber Rejo meskipun dalam kegiatan operasionalnya masih menggunakan sistem manual pada setiap nota transaksi maupun dokumennya, namun dalam pembuatan pelaporannya dan juga arsip dokumen Toko Sumber Rejo sudah menggunakan sistem komputerisasi, sehingga penulis menyarankan agar mengembangkan sistem pada komputernya. Dimana persediaan penjualan barang dagang dapat menggunakan sistem barcode maupun memberikan kode penomoran 
akun pada jenis barang karena Toko Sumber Rejo Semarang memiliki barang dagang yang sangat banyak dengan nama, jenis, dan ukuran yang bermacam-macam, sehingga hal ini dimaksudkan agar mengurangi terjadinya kesalahan pengambilan barang orderan dan pencatatan dalam menginput maupun mengoutput barang yang masuk maupun keluar selain itu juga mempermudah karyawan dalam mengenali barang yang dimaksud.

3. Dalam pelaksanaan kegiatan penerimaan orderan dan juga pembelian Toko Sumber Rejo Semarang dipegang penuh oleh pimpinan sehingga tidak ada pemeriksaan terhadap tugas karyawan yang dilakukan oleh pimpinan dan karena rasa kepercayaan pimpinan akan karyawannya. Hal ini yang terkadang menjadikan karyawan mengabaikan atau kurang teliti dalam menjalankan tugas dan tanggung jawabnya. Oleh karena itu, peneliti menyarankan agar pimpinan toko dalam menjalankan manajemennya tetap melakukan pemeriksaan atas tugas dan tanggung jawab karyawannya agar berjalan sesuai dengan aturan yang ada.

4. Untuk membantu pimpinan dalam menilai apakah sistem pengendalian internal yang dilaksanakan sudah berjalan dengan baik serta menjaga kelancaran usahanya maka peneliti menyarankan perlu adanya audit internal dalam Toko Sumber Rejo Semarang, dimana dengan adanya audit internal akan banyak manfaat yang dapat diperoleh pimpinan toko.

\section{PENUTUP}

\section{Kesimpulan}

Berdasarkan dari hasil analisis dan pembahasan diatas dapat diambil kesimpulan sebagai berikut:

1. Penerapan sistem pengendalian internal pada Toko Sumber Rejo belum bisa dikatakan baik karena tidak adanya struktur organisasi yang memadai, serta masih adanya fungsi ganda dalam pelaksanaan tugas dan tanggung jawab.

2. Pelaksanaan pengendalian internal penjualan barang persediaan penjualan barang dagang masih belum berjalan dengan tepat dan efektif, hal ini menyebabkan terjadinya selisih antara pencatatan dengan bukti fisik barang yang ada. 
3. Terdapat banyak barang yang memiliki nama, jenis, dan ukuran yang hampir sama membuat terjadinya ketidak sesuaian barang orderan dengan barang yang diinput maupun dioutput ke komputer.

\section{Saran}

Sebaiknya perusahaan pemisahan tugas dan tanggung jawab pada setiap karyawan, sehingga karyawan dapat fokus dengan tanggung jawabnya, serta menerapkan sistem barcode maupun penomoran dengan akun dalam barang dagang agar meminimalisir kesalahan dalam pencatatan barang, serta dilakukannya pemeriksaan mendadak pada setiap karyawan agar karyawan melaksanakan tugasnya sesuai dengan aturan yang ditetapkan dan lebih bertanggung jawab serta membentuk audit internal untuk membantu pimpinan dalam penilaian.

\section{Keterbatasan Penelitian}

Penelitian ini hanya terbatas pada Toko Sumber Rejo selain itu terbatasnya segi waktu, biaya, dan tenaga sehingga tidak dapat melakukan perbadingan sistem pengendalian yang dilaksanakan pada toko yang sejenis. Keterbatasan peneliti dalam menyusun dan mewawancarai informan.

\section{Agenda Penelitian Selanjutnya}

Peneliti menyarankan untuk penelitian selanjutnya data menggunakan perusahaan lain yang sejenis untuk bahan pembanding dan juga menambahkan jumlah informan sehingga hasil yang dihasilkan akan mendekati kondisi sesungguhnya.

\section{DAFTAR PUSTAKA}

Akbar, Rusdi, 2004, Pengantar Akuntansi, UPP AMP YKPN, Yogyakarta.

Fernando, Johan, 2016, Peranan Sistem Informasi Akuntansi Persediaan Barang Dagang Terhadap Efektivitas Pengendalian Internal Pada Pt. Meskom Agro Sarimas Divisi Amdk (Air Minum Dalam Kemasan), ISSN, 2541-3023.

Gunawan, Imam, 2015, Metode Penelitian Kualitatif Teori \& Praktik, Bumi Aksara, Jakarta.

Mulyadi, 2017, Sistem Akuntansi, Edisi Keempat, Salemba Empat, Jakarta.

Putra, Rizki Eka, 2018, Analisis Sistem Informasi Akuntansi Dan Pengendalian Intern Persediaan Bahan Baku Kain (Studi Kasus CV. Celine Production), ISSN, 25031546.

Rahayu, Irna Dwi. Dkk, 2016, Analisis Sistem Pengendalian Intern Persediaan Obat Di Rumah Sakit Anak Astrini Wonogiri, ISSN, 2337-4349

Soemarso, S.R, 2004, Akuntansi Suatu Pengantar, Edisi Lima (Revisi), Salemba Empat, Jakarta. 
Sugiri, Slamet, 2005, Akuntansi Pengantar 2, Edisi Empat, UPP AMP YKPN, Yogyakarta.

Suprajitno, Dwi, 2008, Sistem Pengendalian Intern Terhadap Persediaan Bahan Baku Pada PT Surya Indah Kebumen, Jurnal Fokus Bisnis, Volume 7.

Warren, Carl S et.al, 2009, Pengantar Akuntansi, Salemba Empat, Jakarta.

Warren, Carl S et.al, 2017, Pengantar Akuntansi 1-Adaptasi Indonesia, Edisi Empat, Salemba Empat, Jakarta.

Wildana, Fitri Nur \& Erni Unggul Sedya Utami, 2017, Analisis Sistem Pengendalian Persediaan Atas Barang Dagang Pada CV. Sumber Alam Sejahtera Tegal, ISSN, 2549-5046. 